\title{
Manual Scavenging and Technological Solution to Eradicate It. (Turning Scavengers to Engineers)
}

\author{
Mr. Rajesh Pant, Mr. Mayank Uniyal, Mr. Prashant Ratodi (Asst Professors) \\ Bhawesh Mehta Tarun kumar, Zaki-ur-Rehman,Gurpreet Singh (Students) \\ Tula's Institute the Engineering and Management College Dhoolkot, Dehradun
}

\begin{abstract}
This report targets current scenario in manual scavenging and evils associated with it. It also includes technological solution in form of a concept called KATHA-RISMA which means cleaning. The prima-facie of this research paper is to TURN SCAVENGERS TO ENGINEERS. The scope of this report is to bring this evil into limelight and suggest means to eradicate it. It concludes that the stigma attached to manual scavenging and the demeaning conduct in itself are proves of the failure of the socialism, of the leaders and of the people at large and in this way the article projects the need of a social transformation through generation of awareness and strict implementation of technology in order to meet the constraints of moral regime in which this struggle now lives. I further ask this question is it the life of dignity? The first half of this report will specifically focus on India's current policies and the later half will try to provide technological insight into this. The technology of KATHA -RISHMA uses simple electromechanical components which works like a automated device and cleans the toilets without manual application. The self adjustable brushes are designed keeping in mind the surface geometry of the pot and works on the principle of simple razor blade which takes the adjust according to the face geometry.
\end{abstract}

Keywords: manual scavenging, sewage engineers, socialism, katha-risma

\section{Introduction}

It is a widely acclaimed complaint that in current discussion of social progress "our eyes are turned, not upon hopes and possibilities and positives, but rather upon despair, Impossibilities and negatives." [1] The merit of this complaint can't be questioned in so far as we are witnessing the growing gap between the expectations and the reality, the promises and the performances, the enactments and there implementations. The net difference is so high that it has resulted into despair, and has consequently developed a feeling of helplessness, deception, alienation and anger.[2]John F. Kennedy observed at some point of time that "If a free society can't help them any who are poor it can't save the few who are rich."[3] In our free society, called India there is many who are living at the threshold in expectation of help from the government and the people and unfortunately for them the helplessness and inactivity has touched the threshold of the situation. Well I am referring to the problem of manual scavenging and this reference has great significance when we take into account the fact that Article-1 of the Universal Declaration of Human rights[4] proclaims that, "All human beings are born free and equal in dignity and rights", and the fact that the year 2008 was declared by the General Assembly of the United Nations as the international year of sanitation with focus from global movement to local action.[5]With respect to our country the problem of Scavenging has even greater significance where the father of nation observed that, "I may not be born again and if it happens, I will like to be born in a family of scavengers so that I may relieve them of inhuman, unhealthy and hateful practice of carrying head loads of night-soil."'6].The scourge of scavenging was prevalent during that time also and Mahatma Gandhi put his all efforts and became the voice of untouchables but the current scenario is not at all satisfactory.

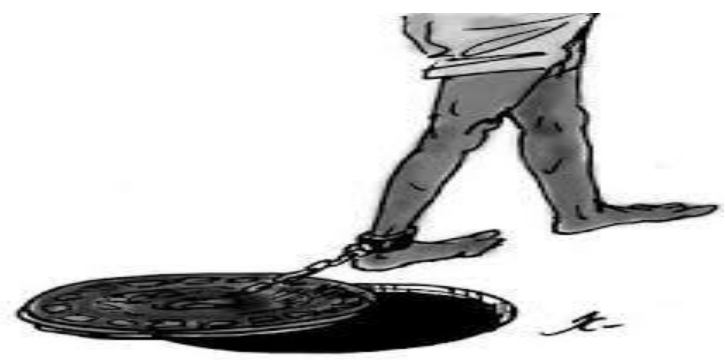




\section{Definition of manual scavenging}

There are a very large number of people engaged in manual scavenging in different parts of the country, in rural areas as well as urban areas.[7].According to the Employment of Manual Scavengers and Construction of Dry toilets(Prohibition) Act, 1993 and The National Commission for Safai Karmchari's Act" manual scavenger" or "safai karmachari" means a person engaged in or employed for manually carrying human excreta.[8] Manual scavenging includes sweeping night soil on the street (dry excreta) followed by cleaning of water borne toilets. It also includes removal of bodies and dead animals followed by sewerage sweeping, and carrying night soil by basket/bucket or on head. The scavengers crawl into the dry excreta and collect the human excreta with bare hands, carry it as head-load in a container to dispose it off. It is also generally believed that after the advent of the Muslims in India 'sweeping and scavenging seems to have taken the form of a formal profession. It is said that the system of bucket privies was designed and constructed by Muslims for their women in 'pardah'. Those who were made captives were forced to clean toilets, bucket privies and throw off the night-soil at distant places. These captives when freed were not accepted by the society and they formed a separate caste and continued the work of scavenging. During the British period with the setting up of army cantonments and municipalities, a large number of people were required to do these services on a regular basis.

\section{The white man's burden became the head load of scavengers.[8] \\ How did it develop?}

In India, the Mughal ruler Jehangir built a public toilet at Alwar, $120 \mathrm{~km}$ away from Delhi for 100 families in 1556 AD.[9] Not much documentary evidence exists about its maintenance. Scholars have suggested that the Mughal women with purdah required enclosed toilets that needed to be scavenged. [10]They point out that the bhangis share some of the clan names with Rajputs, and propose that the bhangis are descendants of those captured in wars. There are many legends about the origin of bhangis, who have traditionally served as manual scavengers. One of them, associated with Lal Begi bhangis describes the origin of bhangis from Mehtar Ilias.[11]Municipal records from 1870 show that the British organized municipalities in India which built roads, parks, public toilets etc. [12]The British administrators organized systems for removing the night soil and employed bhangis[13]

On the basis of census data, Risley, the Commissioner for 1901 Census, classified castes into seven main categories according to their social standing and ranked the Jatis in the local hierarchy and varna affiliation of each.The scavenging castes which were known by different names in different States like Bhangi, Balmiki, Chuhra, Mehtar, Mazhabi, Lal Begi, Halalkhor etc. in northern India; Har, Hadi, Hela, Dom and Sanei etc. in eastern India;Mukhiyar, Thoti, Chachati,Pakay, Relli etc. in Southern India ;and Mehtar, Bhangias, Halalkhor, Ghasi, Olgana,Zadmalli, Barvashia, Metariya, Jamphoda and Mela etc. in Western and Central India,also made an effort to get united and have a common name. In 1911 census some of them started returning as Adi Dharmi, Adi Dravida, Adi Karnataka and Adi Andhran .[14]

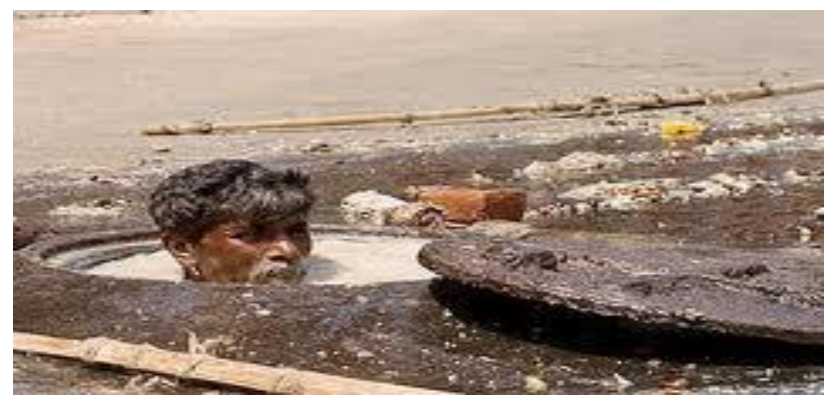

\section{Current prevalence}

Manual scavenging still survives in parts of India without proper sewage systems. It is thought to be most prevalent in Gujarat, Madhya Pradesh, Uttar Pradesh, and Rajasthan.[15]Some municipalities in India still run public dry-toilets. The biggest violator of this law in India is the Indian Railways which has toilets dropping all the excreta from trains on the tracks and they employ scavengers to clean it manually. [16]

\section{Magnitude of the problem}

Though long outlawed, the practice of manual scavenging continues in most states. Those working privately are paid very less for each house they clean. In many communities, in exchange for leftover food, scavengers are also expected to remove dead animal carcasses and deliver messages of death to the relatives of their upper-caste neighbors. Their refusal to do so can result in physical abuse and ostracism from the community.Further the number of persons employed as scavengers is uncertain because no reliable baseline data 
is available.[17]In fact, According to the census of March 1991 there were expected to be 4 lakh manual scavengers among which $83 \%$ were found to be in the urban areas and $35 \%$ of the scavengers were found to be women. According to the data given by the Ministry of Social Justice and Empowerment in March 2003, number has reached to 6.76 lakh.[18]The majority of waste-pickers are women and children.A survey conducted by Safai Karamchari Andolan, an NGO movement for the elimination of manual scavenging, revealed that 98 percent of manual scavengers in the state belonged to scheduled castes.[19] In January 2005, the Supreme Court, hearing a petition filed in 2003 by the Safai Karmachari Andolan and 13 other organizations and individuals, observed that the number of manual scavengers in India has increased. Even in Mahatma Gandhi's Gujarat the situation is pathetic. There are about 55,000 scavengers in Gujarat, according to the Navsarjan Trust, which has been leading the movement in the State. Its founder, Martin Macwan, believes that it is impossible to determine correctly the size of the problem because people refuse access to their homes. "We can know only about those employed with the government, local civic bodies or panchayats. The estimates are based on the population of Balmikis, the kindof work they engage in, and sample surveys," he says. "The State government does nothing except allocate money. The scavengers are made to believe that this is their work and they cannot do anything else, so they don't want to talk about it."

\section{Implications: untouchables among untouchables}

Some major implications of manual scavenging:

$>$ Increasing number of waste-pickers is considered a sign of growing poverty. [20] In this way Right to life of scavengers remains under consistent threat.

$>$ Right to equality and dignity are violated due to the continuance of such inhuman practice.

$>$ Right of Food or right against Hunger is violated due to continuance of the evil practice of Scavenging.[21]

$>$ Manual scavengers are exposed to the most virulent forms of viral and bacterial infections that affect their skin, eyes, and limbs, respiratory and gastrointestinal systems. According to the Environmental Sanitation Institute, Gandhi Ashram, the majority of scavengers suffered from anaemia, diarrhoea and vomiting.

$>$ Right to development is also violated.

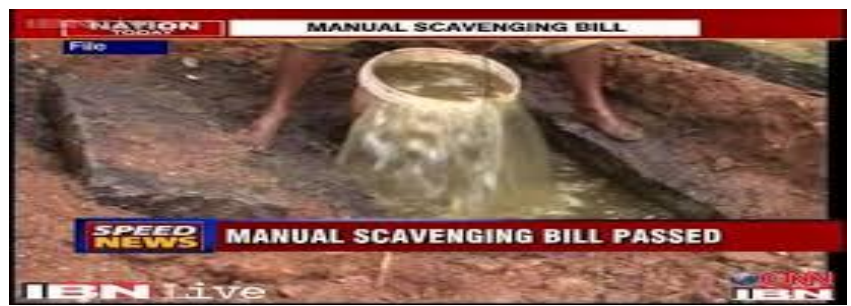

What blog and research says

$>$ Recent UN research in India, the world's second most populous country, shows roughly 366 million people (31 per cent of the population) had access to improved sanitation in 2008.

$>$ Zafar Adeel, Director of United Nations University's think tank says: "It is a tragic irony to think that in India, a country now wealthy enough that roughly half of the people own phones, about half cannot afford the basic necessity and dignity of a toilet."

$>$ Soutik Biswas Delhi correspondent says ((Mahatma Gandhi, India's greatest leader, had, in the words of a biographer, a "Tolstoyian preoccupation with sanitation and cleaning of toilets". Once he inspected toilets in the city of Rajkot in Gujarat. He reported that they were "dark and stinking and reeking with filth and worms" in the homes of the wealthy and in a Hindu temple. The homes of the untouchables simply had no toilets. “

\section{What does act says?}

COIMBATORE: Although the Act banning manual scavenging came into force in 2013, it has not been sufficient to get rid of this evil. Various organizations involved in efforts to support manual scavengers and rehabilitate them say that the government should enforce the act in letter and spirit. Only then can we succeed in eradicating this practice and rehabilitating victims. The Act which was passed in the Parliament in 2013 bans employing of manual scavengers and aims for their rehabilitation by providing alternate jobs. It is estimated that there are around 45,000 manual scavengers in the state. This act was brought in to substitute an earlier act which was passed in 1993. The latest act has more stringent norms, but activists say that this is not adequate to meet 
the challenges faced in getting rid of manual scavenging. Employers, including government departments and agencies, especially local bodies that have employed a large number of such people, have not been serious about resolving the issue.

Activists allege that the government has not been serious about eradicating this evil. "The act says that scavengers should be replaced with machinery and technology. However, the required machines have not been bought. The safety equipment including gloves is not fit for use," said R Selvam, General Secretary of Ambedkar Manual Scavengers Trade Union. Many organizations including the corporation continue to use open barrels for moving waste which is hazardous.

In many parts of India, the inhuman practice of manual scavenging continues to thrive in spite of a law banning it. Moreover, the people forced to carry out this degrading work remain invisible to the rest of us, pushed to the margins of society. Based on more than a decade of research, Unseen unveils the horrific plight of manual scavengers across 11 states while also recording their ongoing struggle for self-empowerment.

\section{How can technology help and turn scavengers into engineers.}

I believe that if we can hand over some gadget to the people engaged in toilet cleaning it could help them in making them comfortable. Not only people watching them will feel better about them but this would also raise their self esteem. This way they can be part of new breed of social engineers.

Initially this product will focus on the hotels industry and other big houses where it could be easily sold. Once enough market is established this could be on the reach of every common people.

Katha risma itself means cleaning. Through this paper I also welcome all those who wish to finance this project.

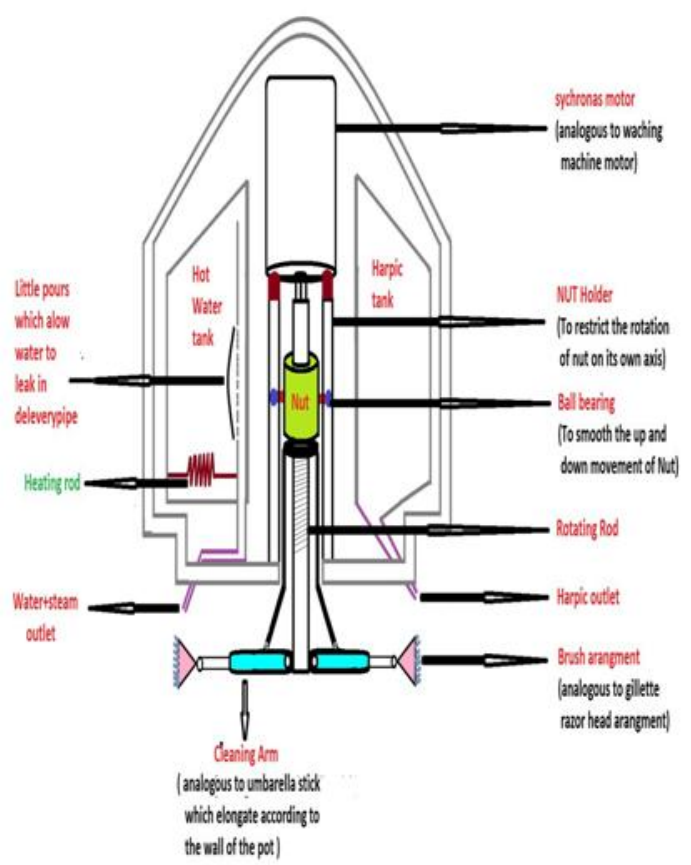

Fig 1.key features of the toilet cleaner (basic sketch)

This machine will be used by the people involved in cleaning of toilet pots in hotels and business houses. They just have to put this machine over the pot and switch on the start button.

The brushes will move in umbrella mechanism and at the same time the main spindle will rotate at its axis clockwise and anti clockwise. The brushes will take the position which corresponds to the fig no 2,3 and 4 respectively and finally the pot will be cleaned. 


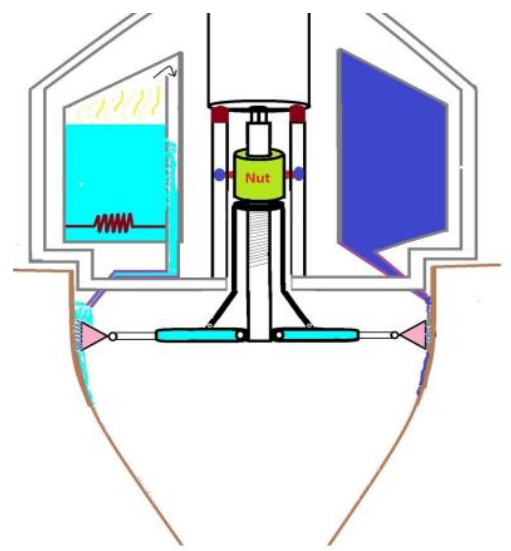

Fig 2.Stage1-brush is at initial position of cleaning in pot

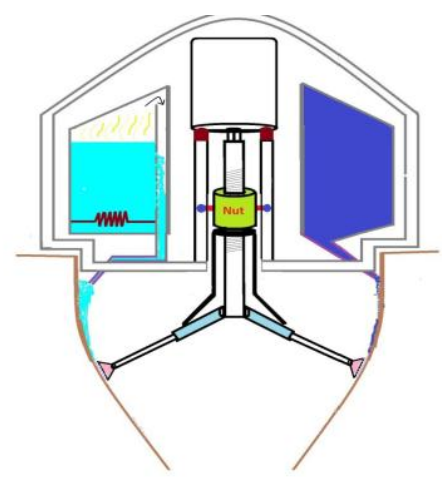

Fig 3.Stage2-brush is at intermediate position

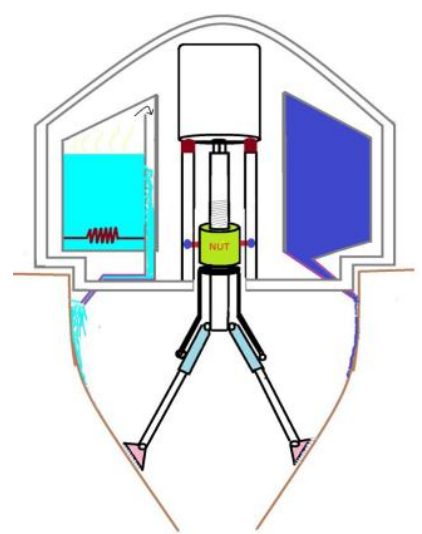

fig 4. Stage 3-brush is at extreme bottom position

\section{Different assembly parts}

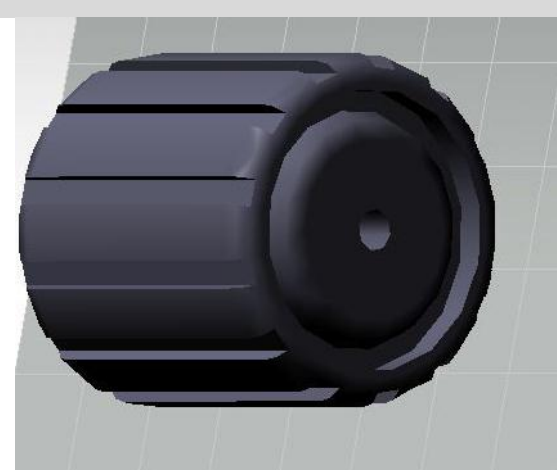

Fig5.Motor 


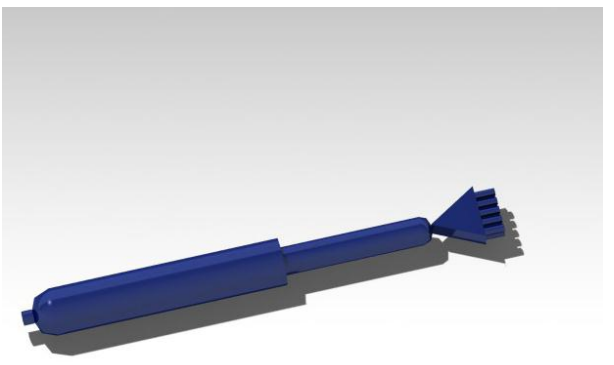

Fig 6. Brush

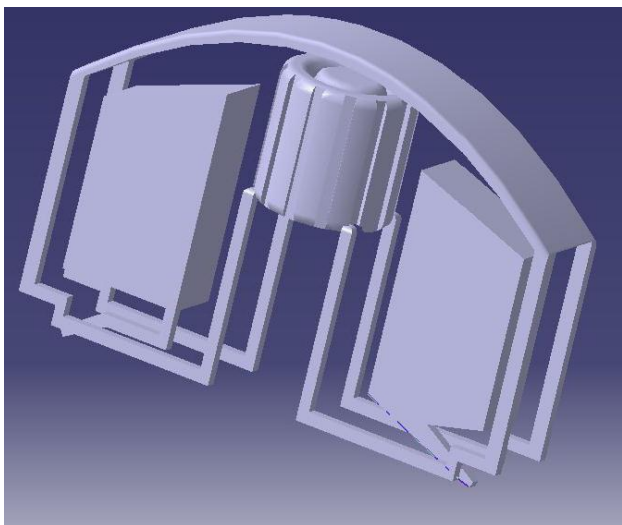

Fig7. Motor with frame

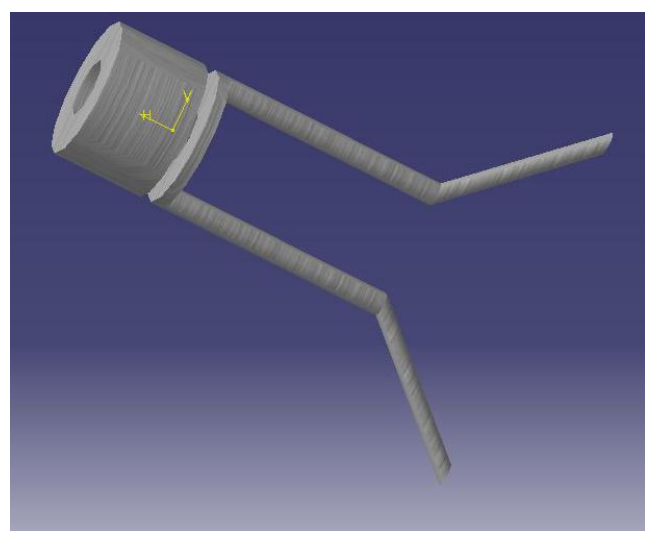

Fig 8.nut

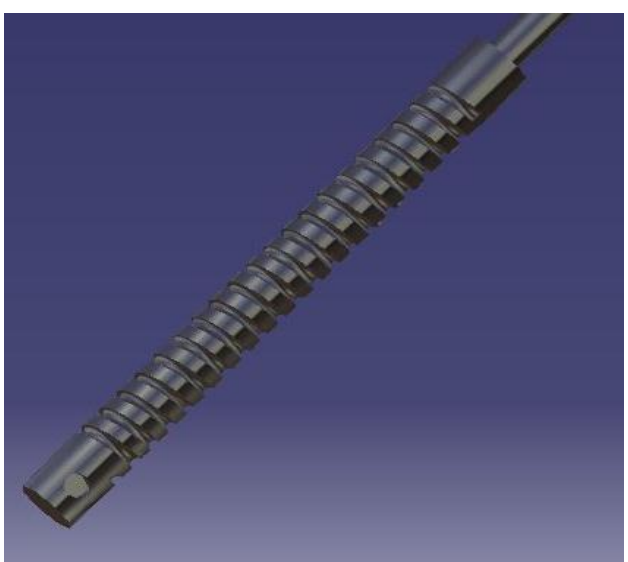

Fig 9 Spindle with thread 


\section{Different views of machine in Ansys}

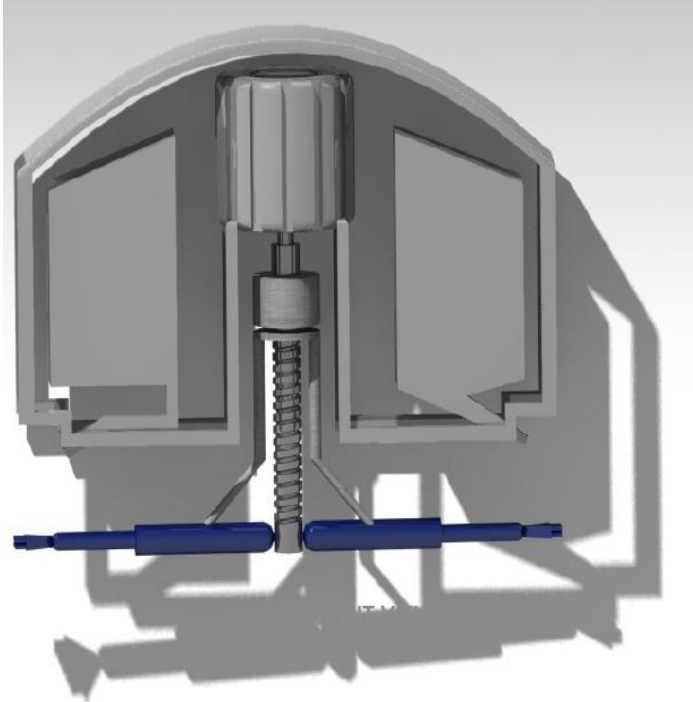

Fig10. Front view

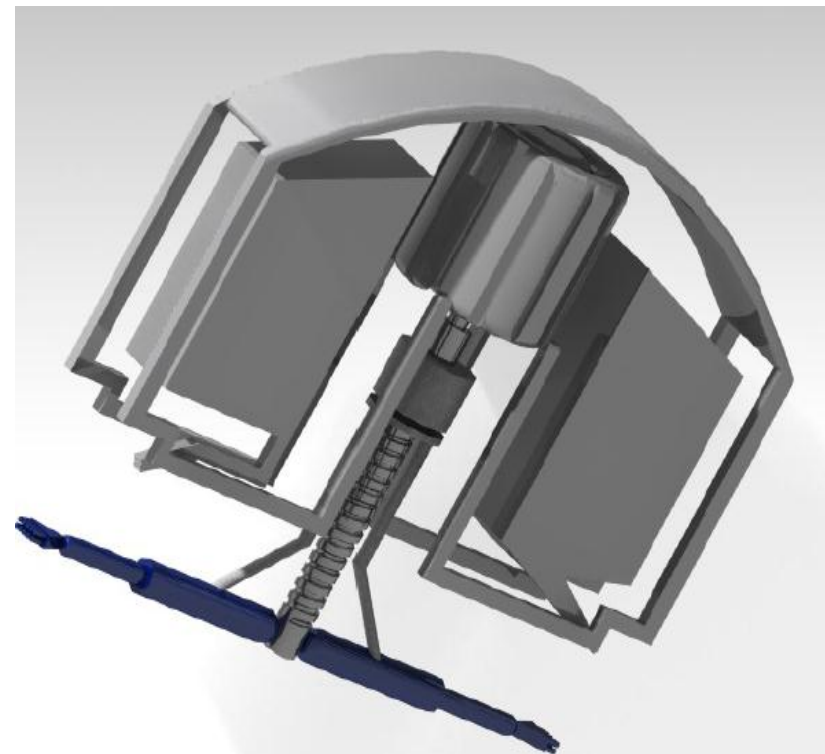

Fig 11.Isometric view

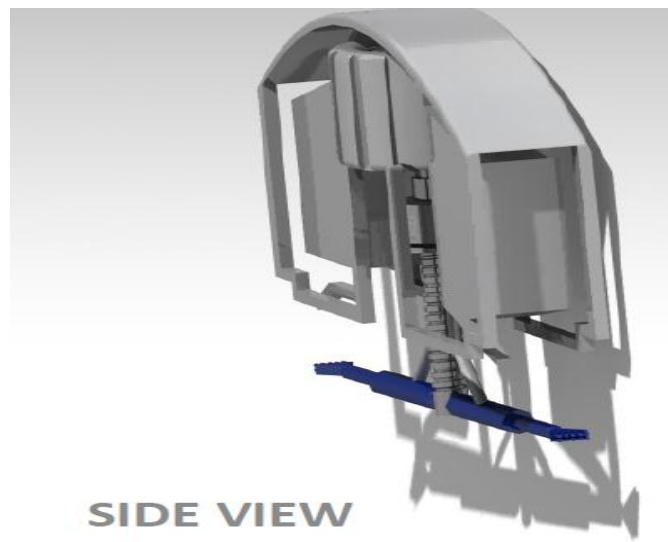

Fig12.side view 


\section{Conclusion}

Manual scavenging a caste based and hereditary profession, which is handed down, as a legacy from one generation to the next; it has been an age-old routine for this community, which is untouched by technological advancement in sanitary practices. What is worse is the fact that those born in this community are considered agents of pollution due to their background of social hierarchy, based on birth. They are the most oppressed and suppressed class of Indian society - hated, and avoided by all other castes and classes. The appalling hardship, humiliation and exploitation they face, have no parallel in human history. The practice started in the Pauranic period continued in the Buddhist, Mauryan, Mughal and sadly still continued. We all are lucky to witness and use technology like mobile phones and internet but a big question again arises, are they really lucky?

\section{Its time to seek help and let technology turn those scavengers into engineers.}

\section{References}

[1] Sanitation and Social Progress Author(s): William H. Allen,The American Journal of Sociology, Vol. 8,No. 5, (Mar., 1903), pp. 631-643.

[2] V. R. Krishna Iyer, Justice at Crossroads, Deep and Deep Publications, New Delhi, 1994, p. 265

[3] John F. Kennedy, inaugural address, January 20, 1961, 35th president of US 1961-1963 (1917 - 1963).

[4] Adopted and proclaimed by General Assembly resolution 217 A (III) of 10 December 1948.

[5] The General Assembly of the United Nations through its Resolution A/C.2/61/L.16/Rev.1 dated 4December 2006 declared 2008 as an International Year of Sanitation.

[6] It is worth noting here that, Mahatma Gandhi raised the issue of the horrible working and socialconditions of bhangis more than 100 years ago in 1901 at the Congress meeting in Bengal. Yet it tookabout 90 years for the country to enact a uniform law abolishing manual scavenging. See Bipin Chandra, India’s Freedom Struggle, Penguin.

[7] Report of the 2nd Labour Commission.

[9] Pathak, Bindeshwari, http://www.behind-the-open-door.com/_pdf/sulabh.pdf/Present_Dalit_...pdf. [10]Bindeshwar Pathak, Toilet History The Vacuum - Issue 18

[11] Road to Freedom: A Sociological Study on the Abolition of Scavenging in India, Bindeshwar Pathak, Motilal Banarsidass Publishe, 1999. p. 38

[12] The Bhangi: A Sweeper Caste, Its Socio-economic Portraits : with Special Reference to Jodhpur City, Shyamlal, Popular Prakashan, 1992 p. 21

[13] Themes in Indian History,Dr. Raghunath Rai, FK Publications, 2010, p. 246

[14] Scavenging, Volume 17, Bombay (India : State), Government Central Press, 1884, p. 676-679

[15] Srivastava, B.N. (1997). Manual Scavenging in India: A Disgrace to the Country. Concept Publishing Company (P) Ltd. p. 178. ISBN 8170226392

[16] Manual scavengers become fashion models." BBC. 4 July 2008

[17] "Manual Scavengers: Indian Railways in denial". OneWorld South Asia. 25 February 2013.

[19] Report preapared by TISS titled "Study of Practice of Manual Scavenging in Gujarat".

[20] Frontline, Volume 23 - Issue 18 :: Sep. 09-22, 2006

[22] Themes in Indian History,Dr. Raghunath Rai, FK Publications, 2010, p. 246

[23] Frontline, Volume 23 - Issue 18:: Sep. 09-22, 2006

[24] [Pelletier, D.: The relationship between child anthropometry and mortality in developing countries. J. Nutr. (Supplement) 124, 2047S-2081S (1994)] 